КУЗНЕЦОВА Наталия Алексеевна - кандидат политических наук, доцент кафедры теории политики и коммуникации Нижегородского государственного университета им. Н.И. Лобачевского (603950, Россия, г. Нижний Новгород, ул. Ульянова, 2; natkuzпеt@таil.ru)

ОРЛИНСКАЯ Ольга Михайловна - кандидат политических наук, доцент кафедры теории политики и коммуникации Нижегородского государственного университета им. Н.И. Лобачевского (603950, Россия, г. Нижний Новгород, ул. Ульянова, 2; orlinskaya@таil.ru)

МОЛОКИНА Екатерина Георгиевна - студентка Института международных отношений и мировой истории Нижегородского государственного университета им. Н.И. Лобачевского (603950, Россия, г. Нижний Новгород, ул. Ульянова, 2; kataymolo1@rambler.ru)

\title{
ЛИБЕРТАРИАНСТВО В РОССИИ И США: К ВОПРОСУ О РАЗЛИЧИЯХ
}

Аннотация. В статье рассматриваются вопросы содержания либертарной политической доктрины. Авторы выявляют различия во взглядах классиков американского либертарианства и современных российских адептов этой доктрины и приходят к выводу о большем интересе к идее прогресса у российских либертариев по сравнению с американскими.

Ключевые слова: либертарианство, минархизм, анархо-капитализм, отличия, прогресс, Россия, США

$\mathrm{O}$ дной из модных политических доктрин (пусть пока и в рамках Рунета) в современной России является либертарианство [Устинкин, Рудаков 2017: 56]. В «общем смысле либертарианство (или либертаризм) можно понимать как философскую доктрину и основанную на ней идеологическую систему, утверждающую приоритет индивидуальной свободы в социальной жизни» [Максимец 2015: 70]. В рамках либертарианства можно выделить две разновидности. Первой из них является минархизм, при котором власть должна ограничивать себя в защите прав личности и обеспечении их безопасности (государство как «ночной сторож»). Другая позиция представлена анархокапиталистами, которые хотят заменить государство частными охранными агентствами и судами, конкурирующими на открытом рынке услуг [Płaszczyca 2014: 29]. Наиболее видным адептом минархизма считается американский мыслитель Р. Нозик, а анархо-капитализма - философ и экономист из США М.Н. Ротбард.

В качестве иллюстрации равенства между этими двумя разновидностями либертаризма укажем следующее: если Р. Нозик не отрицал необходимость наличия государственных правоохранительной и судебной систем, то М.Н. Ротбард в первой главе своей книги «Власть и рынок» доказывал, что частная полицейская, военная и судебная деятельность является единственным истинным способом для мужчин быть полностью свободными. Он объяснял, что частные полицейские и судебные системы на свободном рынке были бы эффективными и справедливыми [Block 2002: 150]. Адепты анархокапитализма считают, что на охрану люди должны будут подписаться, если они хотят защиты [Block 2002: 151].

При этом возникают вопросы, связанные с функционированием охранных структур в случае реализации анархо-капиталистического проекта. В самом деле, сотрудники этих структур должны взять на себя некоторые обязательства, которые могут считаться рабским трудом. Что будет, если недостаточное число людей захотят добровольно присоединиться к этим структурам? Следует ли в этом случае прибегать к той или иной форме обязательной службы? Если это будет сделано, не будет ли поставлена под угрозу сама либертарная кон- 
цепция? [Salahuddin 2017]. Кроме того, что будет, если не все люди «подпишутся» на оплату услуг по их охране? Гипотетически рассмотрим следующую ситуацию: порядок на некоей территории обеспечивает частное охранное агентство. Часть жителей добросовестно оплачивают его услуги. Другие же жители полагают, что раз они не обращаются за помощью к этому агентству, то и они ничего ему не должны. Если же учесть, что охранное агентство не только реагирует на преступления, но также и в какой-то мере занимается профилактикой преступной деятельности (а сам факт эффективности борьбы с преступностью можно признать и профилактикой!), то получается, что не платящие охранному агентству попросту пользуются его услугами даром. Заставить же их заплатить за по сути оказанные услуги невозможно. Принцип справедливости при таком положении явно нарушен.

В российских реалиях анархо-капитализм получил меньшее распространение, нежели минархизм (едва ли не наиболее ярко это иллюстрируется следующей цитатой: «Если б человек был всегда добр, то и государства не было б надо» $\left.{ }^{1}\right)$. Из наиболее ярких и известных его адептов упомянем Ю.Л. Латынину и А.П. Никонова [Пахомова, Сальников, Фомичев 2018: 45]. По нашему мнению, взгляды этих двух либертариев отличаются как от взглядов Р. Нозика, так и от взглядов М.Н. Ротбарда. Разумеется, и Ю.Л. Латынина, и А.П. Никонов крайне положительно оценивают творчество А. Рэнд, критикуют государство за излишнее вмешательство в дела граждан и бизнеса (яркий пример - следующая цитата из А.П. Никонова: «Государство всячески подыгрывает такому проявлению безответственности, недвусмысленно давая гражданам понять, что они слишком безответственны и глупы, чтобы самостоятельно устроить даже собственную жизнь» [Никонов 2005: 29]). Их также не устраивает излишняя политкорректность, феминизм и левая социальная политика. Однако при этом для обоих российских адептов либертаризма характерно комплиментарное отношение к ряду современных российских и иностранных государственных деятелей, например к Д. Трампу, С. Собянину и ряду других. Причина такого положения дел, судя по всему, заключается в том, что уважаемые либертариями политики содействуют прогрессу на вверенной им территории.

А.П. Никонов дошел до преклонения не только перед Наполеоном I (не только за его кодекс, но также за цивилизаторскую деятельность в целом), но даже перед Римской империей. В частности, он пишет следующее: «Можно сказать, это был первый проект объединенной Европы. Сейчас вместо одного государства на месте древней империи 36 разных стран. А когда-то... Единая финансовая система. Один язык международного общения - латынь. Единая система мер и весов. 〈... Единые системы местного самоуправления и судопроизводства, составления юридической и торговой документации. <... Все свободные граждане империи обретают полноправное римское гражданство. Римский город в Африке становится похожим на римский город в Германии. Культурный плавильный котел» [Никонов 2010: 12].

Иначе говоря, видные российские идеологи либертарианства, в отличие от американских единомышленников, толерантнее относятся к государству, если оно объективно содействует прогрессу. В ряде случаев они готовы даже поддержать вполне авторитарного государственного деятеля, борющегося с левыми. Представить же себе американских либертариев, поддерживающих, к примеру, А. Пиночета, вряд ли возможно [Устинкин, Рогожина 2012: 196].

1 Латынина Ю. Код доступа. - Эхо Москвы. 18 августа 2018. Доступ: https://echo.msk.ru/programs/ code/2260918-есhо/ (проверено 30.06.2018). 


\section{Список литературы}

Максимец С.В. 2015. Концепции либертарианства в социальной философии.

- Российский научный журнал. № 2(45). С. 70-71.

Никонов А.П. 2005. Конеи феминизма: чем женщина отличается от человека. М.: Изд-во НЦ ЭНАС. 253 с.

Никонов А.П. 2010. Судьба цивилизатора: теория и практика гибели империй. М.: Изд-во НЦ ЭНАС. 358 с.

Пахомова Е.А., Сальников М.В., Фомичев М.Н. 2018. Слабости современной российской либертарианской правовой концепции. - Правовое государство: теория и практика. Т. 1. № 51. С. 43-48.

Устинкин С.В., Рогожина Е.М. 2012. Западноевропейская модель политического лидерства. - Власть. № 10. С. 195-197.

Устинкин С.В., Рудаков А.В. 2017. Идентичность - объект современного глобального противоборства. - Обозреватель - Observer. № 9(332). С. 53-61.

Block W. 2002. The Libertarian Minimal State: a Critique of the Views of Nozick, Levin and Rand. - The Journal of Ayn Rand Studies. Vol. 4. No. 1. P. 141-160.

Płaszczyca M. 2014. The Ethical Aspect of the Relationship of the Individual and the State in the Libertarian Perspective of Murray N. Rothbard. - Annales: etyka $w$ zyciu gospodarczym. Vol. 17. No. 4. P. 23-34.

Salahuddin A. 2017. Robert Nozick's Entitlement Theory of Justice, Libertarian Rights and the Minimal State: A Critical Evaluation. - Journal of Civil \& Legal Sciences. Vol. 7. Iss. 1.

KUZNETSOVA Nataliya Alekseevna, Cand.Sci. (Pol.Sci.), Associate Professor of the Chair of Theory of Politics and Communication, Lobachevsky State University of Nizhny Novgorod (2 Ul'yanova St, Nizhny Novgorod, Russia, 603950; natkuznet@mail.ru)

ORLINSKAYA Olga Mikhaylovna, Cand.Sci. (Pol.Sci.), Associate Professor of the Chair of Theory of Politics and Communication, Lobachevsky State University of Nizhny Novgorod (2 Ul'yanova St, Nizhny Novgorod, Russia, 603950; orlinskaya@mail.ru)

MOLOKINA Ekaterina Georgievna, student of the Institute of International Relations and World History, Lobachevsky State University of Nizhny Novgorod (2 Ul'yanova St, Nizhny Novgorod, Russia, 603950; kataymolo1@rambler.ru)

\section{LIBERTARIANISM IN RUSSIA AND THE UNITED STATES: TO THE QUESTION OF THE DIFFERENCES}

Abstract. The article deals with the content of the libertarian political doctrine. The authors reveal differences in the views of the classics of American libertarianism and modern Russian adherents of this doctrine. They conclude that Russian libertarians are more interested in the idea of progress in comparison with American ones.

Keywords: libertarianism, minarchism, anarcho-capitalism, differences, progress, Russia, USA 